\title{
GRAFTING FOR THE RECOVERY OF YELLOW PASSION FRUIT STEM IN ORGANIC SYSTEM ${ }^{1}$
}

\author{
MARIA IZABEL FREITAS LINS REZENDE², SEBASTIÃO ELVIRO ARAÚJO NETO³, \\ CAMILA LUSTOSA ${ }^{4}$, OSCAR MARIANO HAFLE 5 , GEAZI PENHA PINTO 6
}

\begin{abstract}
The aim of the present study was to evaluate the effect of stem repair grafting on the recovery of damaged plants, yield and quality of yellow passion fruits in organic system. The experiment was conducted simulating five stem damages (treatments) in randomized complete block design with four replications of four plants each. After reaching on average $7.3 \pm 1.2 \mathrm{~mm}$ in stem diameter, plants were perforated at 20,40, 60 and $80 \%$ of the stem diameter with the aid of a steel drill. The reduction in plant stand treatment with 80 $\%$ damage reduces plant productivity. Then, bridge-type grafting was performed by connecting the top and bottom of the injury. The grafting success percentage ranged from 81.3 to $95.8 \%$ and did not differ between treatments, but the survival rate of plants was lower in treatments with 40 and $80 \%$ of injuries. There were no statistically significant differences between treatments for the following variables: number of fruits per plant, average fruit weight, total soluble solids (TSS), total titratable acidity (TTA) and (TSS/TTA) ratio. Recovery stem grafting allows injured plants to maintain the same productivity by up to $60 \%$ compared to plants without injuries.
\end{abstract}

Index terms: Passiflora edulis, Philonis passiflora, bridge grafting.

\section{ENXERTIA PARA RECUPERAÇÃO DE CAULE DO MARACUJAZEIRO AMARELO EM SISTEMA ORGÂNICO}

RESUMO - O objetivo deste trabalho foi avaliar o efeito da enxertia de reparação do caule na recuperação de plantas, produtividade e qualidade dos frutos de maracuzajeiro amarelo em sistema orgânico. O experimento foi realizado simulando-se danos no caule em cinco danos (tratamentos), em blocos casualizados com 4 repetições, de quatro plantas cada. Ao atingir em média 7,3 $\pm 1,2 \mathrm{~mm}$ de diâmetro do caule, o maracujazeiro foi perfurado em 20, 40, 60 e 80\% do diâmetro do caule, com auxílio de broca de aço. Em seguida, realizouse enxertia tipo ponte, ligando-se as partes inferior e superior ao dano. O índice de pegamento do enxerto variou de 81,3 a $95,8 \%$, não diferindo entre os tratamentos, porém a taxa de sobrevivência das plantas foi inferior nos tratamentos com 40 e $80 \%$ de dano. A redução do estande no tratamento com $80 \%$ de dano diminuiu sua produtividade. Não houve diferença estatística entre os tratamentos para o número de frutos por planta, massa média de frutos, sólidos solúveis totais, acidez total titulável e ratio (sólidos solúveis/acidez). E, a enxertia de recuperação de caule permite que plantas danificadas em até $60 \%$ do caule, mantenham a mesma produtividade que plantas sem dano.

Termo para indexação: Passiflora edulis, Philonis passiflorae, enxertia tipo ponte.

\footnotetext{
'(Paper 203-15). Received September 02, 2015. Accepted February 22, 2016.

${ }^{2}$ Agronomist, MSc in vegetal Production (UFAC). INCRA Acre. Rio Branco, Acre. email: bebellins@hotmail.com.br

${ }^{3}$ Agronomist. PhD in Plant Science, associate Professor at UFAC, University Campus BR 364 Km 4, Industrial District, CEP 69920900, Rio Branco - Acre. email: selviro2000@yahoo.com.br

${ }^{4}$ Agronomist. Federal University of Acre. email: camila_lustosa_morena@hotmail.com

${ }^{5}$ Graduate in Agricultural Sciences, PhD in Plant Science, Professor at IFAL - Maragogi Campus, Alagoas. E-mail: omhafle@yahoo.com.br

${ }^{6}$ Agronomist. MSc in vegetal Production, Professor at IFAC; email: geazi.pinto@ifac.edu.br
} 


\section{INTRODUCTION}

Passion fruit is among the main commercial fruits, which activity is growing in Brazil, with average yield of $13.4 \mathrm{t} \mathrm{ha}^{-1}$ (IBGE, 2012), but production does not meet the internal demands of the consumer market and is below the crop potential, which can reach 50 t ha $^{-1}$ (RONCATTO et al., 2011a).

Among the main factors that compromise crop productivity are phytosanitary problems. Among them, insects stand out because they change the photosynthetic capacity of plants. Passion fruit stalk borer (Philonis passiflorae O`Brien Coleoptera: Curculionidae) is listed among the main crop pests, which has been reported in several producing states, with outbreaks caused by the indiscriminate use of pesticides that caused biological imbalance (FANCELLI, LIMA, 2004).

This pest reduces the productivity of passion fruits by partially blocking the transport of sap through the stem that culminates with cellular hypertrophy, fruit fall and severe attack, wilting and drying of branches (FANCELLI and LIMA, 2004), reduction of fruit mass and number (FADINI; SANTA-CECÍLIA, 2000). Severe attack on the main stem can lead to plant death, increasing crop damage.

In Brazil, there are no chemicals registered and authorized to control the pest attacking passion fruit trees (MAPA, 2011), which leads to the use of improper products that ultimately generate resistance of pests in crops, as well as pesticide residues in vegetal products above Maximum Residue Limits (MRLs). In organic agriculture, direct pest control is carried out with natural insecticides (oils and extracts of insecticidal plants, syrups and biofertilizers) (ARAÚJO NETO et al., 2014; BRASIL, 2011; LIMA et al., 2013).

Nevertheless, the presence of the insect in the orchard is perceptible only after damage to the plant stem, and control with chemicals or alternative products at this stage only prevents the damage deepening and the insect proliferation in the area, but does not guarantee the recovery of the attacked plant, which can regenerate depending on the damage level.

As cultural control, pruning and destruction of lateral branches with thickening typical of the pest attack is indicated, which is a drastic measure when attack occurs in the main stem (FANCELLI; LIMA, 2004). Grafting techniques are used for the most diverse purposes and can be used in the recovery of fruit and ornamental plants (CÉSAR, 1986; CRASWELLER, 2005), being an option to connect the stem below and above the damage caused, reversing the damage.
In the case of passion fruit culture, studies have shown that grafting techniques are feasible to improve the agronomic characteristics of cultivars (CAVICHIOLI et al., 2011; RONCATTO et al., 2011a; RONCATTO et al., 2011b; SILVA et al., 2011); however, studies on plant recovery grafting are still scarce in literature.

The aim of this study was to evaluate the effect of stem repair grafting on plant recovery, yield and quality of yellow passion fruits in organic system.

\section{MATERIAL AND METHODS}

The experiment was conducted at the Serido Ecological Farm, Rio Branco, capital of the state of Acre ( $9^{\circ} 53$ ' $16^{\prime}$ " 'S and $67^{\circ} 49^{\prime} 11$ ' $\mathrm{W}$, and 150 $\mathrm{m}$ asl), during the period From November 2012 to March 2014. The soil of the experimental area is classified as plinthosol ultisol. The nutrient content in the $0-20 \mathrm{~cm}$ depth layer is: $\mathrm{pH}(\mathrm{H} 2 \mathrm{O})=5,1 ; \mathrm{P}=2$ $\mathrm{mg} \mathrm{dm}{ }^{-3} ; \mathrm{K}=1,8 \mathrm{mmolc} \mathrm{dm}^{-3} ; \mathrm{Ca}=19$ mmolc dm$^{-3}$; $\mathrm{Mg}=9 \mathrm{mmolc} \mathrm{dm}^{-3} ; \mathrm{Al}=8$ and $\mathrm{H}=64 \mathrm{mmolc} \mathrm{dm}^{-3}$; organic matter $=17 \mathrm{~g} \mathrm{dm}^{-3}$; base saturation $=29 \% ; \mathrm{Fe}$ $=530 \mathrm{mg} \mathrm{dm}^{-3} ; \mathrm{Cu}=1.6 \mathrm{mg} \mathrm{dm}^{-3} ; \mathrm{Mn}=99 \mathrm{mg} \mathrm{dm}^{-3}$; $\mathrm{Zn}=2.6 \mathrm{mg} \mathrm{dm}^{-3}$ and $\mathrm{B}=0.17 \mathrm{mg} \mathrm{dm}^{-3}$.

The experimental design was randomized blocks, with four replications and four plants per plot. Treatments consisted of five levels of stem obstruction, represented by perforations of $0,20,40$, 60 and $80 \%$ of the main stem diameter.

For the production of seedlings, Passiflora edulis $f$. Flavicarpa seeds (yellow passion fruit), genotype 02 of the Federal University of Acre (UFAC) were used, which were obtained from sibling plants to maintain genetic uniformity and planted in an area adjacent to that of compatible plants to ensure pollination and ovule fertilization. The material was sown on September 15, 2012, using black plastic polyethylene bags with dimensions of $17.5 \mathrm{~cm}$ in length by $7 \mathrm{~cm}$ in diameter, containing substrate composed of rice husk and soil in proportion of 1 : 1: 1 , plus $10 \%$ of fine coal, $1 \mathrm{~kg} \cdot \mathrm{m}^{-3}$ limestone and $1.5 \mathrm{~kg} . \mathrm{m}^{-3}$ thermophosphate.

The crop conduction system was vertical upright trellis with a flat wire fixed in posts of $2.0 \mathrm{~m}$ in height. The crop spacing was 1.5 meters between plants by 3.0 meters between rows. The reduced row spacing was maintained to verify the survival of plants and the first harvest, a management that according to Andrade Junior et al. (2003), does not interfere with productivity if compared to the usual $3 \mathrm{~m} \times 3 \mathrm{~m}$ spacing.

The planting of seedlings was carried out on November 15, 2012, using the no-tillage system, 
controlling spontaneous weeds using brushcutter. Before planting, liming and pit fertilization were carried out with $500 \mathrm{~g}$ of dolomitic limestone and $200 \mathrm{~g}$ of thermophosphate. All inputs and practices used are in accordance with Normative Instruction No. 46 from October 6, 2011, which regulates organic vegetable and animal production in Brazil (BRAZIL, 2011).

At 231 days after planting (DAP), when plants reached an average of $7.3 \mathrm{~mm} \pm 1.2 \mathrm{~mm}$ of stem diameter at $1.50 \mathrm{~m}$ in height, mechanical perforations of $20 \%, 40 \%, 60 \%$ and $80 \%$ of the stem diameter were performed with the aid of an electric drill and steel drills for wood, with diameter proportional to the stem diameter and damage level. After damage, grafting was performed with one branch per plant. The technique used was bridge-type grafting (CÉSAR, 1986; CRASWELLER, 2005), in which the superior part of the damage is attached to the lower one by an herbaceous stem with diameter of $70 \%$ of the diameter of the damaged stem, using vegetative material of the same species. The procedure was performed by inserting the stem with bevelled end, under two opposing cuts in the bark of the plant located in the upper and lower region of the damage. The graft was then tightly fixed with plastic tapes, which were maintained for 30 days.

The variables analyzed were: grafting success percentage, plant survival, fruit yield, number of fruits per plant, average fruit mass, total soluble solids, total titratable acidity and TSS / TA ratio.

The grafting success percentage was verified at 30 days after grafting, considering healing and permanent green color of the graft. The survival rate of plants was verified 60 days after grafting and determined by the quotient between number of live plants and the number of dead plants.

Passion fruit productivity was evaluated by multiplying the mass of fruits per plant by the number of plants distributed in one hectare and the values expressed in $\mathrm{kg} \mathrm{ha}^{-1}$. The harvests occurred between September 6, 2013 and March 29, 2014, when there was infestation of the stem borer interfering with the effect of treatments. During the experiment, there was plant death caused by the damage and grafting procedure and stem borer infestation, including in treatment without grafting, altering the final plant stand and yield between treatments.

The mean mass of fruits was determined by dividing the fruit yield by the number of fruits harvested in each plot. Weekly evaluations were carried out for this variable from September 2013 to March 2014, with peak production in the months of October, November and December.

The chemical quality of fruits was analyzed in ten fruits per plot, harvested on the day of the analysis. For the determination of total soluble solids (TSS), direct reading of juice drops was performed in a digital refractometer with automatic temperature control and accuracy of $0.10{ }^{\circ}$ Brix. Total titratable acidity (TTA) was determined by titrating $1 \mathrm{~mL}$ of juice diluted in $49 \mathrm{~mL}$ of distilled water with 0.1 $\mathrm{N} \mathrm{NaOH}$ solution, expressed as a percentage of citric acid, according to methodology described by the Association of Official Agricultural ChemistsAOAC (2012).

The statistical analysis of data began with the verification of the presence of outliers by the Grubbs test, normality of errors by the Shapiro-Wilk test and variance homogeneity by the Bartlett test. After verification of the assumptions, analysis of variance was performed by the $\mathrm{F}$ test, and comparison of means by the Tukey test. The variables that did not meet the assumptions for parametric statistics were submitted to non-parametric statistics by the Friedman test. To evaluate the comparison of means of variables with reference values obtained in other studies, Student's t-test was performed.

\section{RESULTS AND DISCUSSION}

There was no significant difference between treatments for the grafting success percentage, which ranged from $81.3 \%$ in plants with $40 \%$ damage to $95.8 \%$ in those with $20 \%$ damage (Table 1 ), indicating that the species adapts well to the bridgetype restoration grafting technique, with graft healing (Figure 1).

One of the factors that favored grafting success and healing was the use of vegetative material of the same species, which according to CAVICHIOLI et al. (2011) and SILVA et al. (2011), provides greater compatibility between graft and rootstock. Studies on grafting and rootstock types confirm that the genus passiflora has good acceptance of grafting techniques, including interspecific grafts, with grafting success results greater than $70 \%$ (RONCATTO et al., 2011a), reaching values above $87 \%$ for intraspecific combination (RONCATTO et al., 2011b).

In the grafting process, younger bionts generally provide higher grafting success rates due to the more intense cellular activity, which facilitates the healing process (FACHINELLO et al., 2005). On the other hand, grafts on adult plants present greater difficulty in the welding of tissues due to isoporation 
(RONCATTO et al., 2011b) and also to the greater presence of lignin. This reason may have contributed to the unsuccessful grafting of $100 \%$ of grafts.

The lower survival rate of grafted plants was verified in plants that suffered $80 \%$ damage, being attributed to the greater lesion area of the stem, in which the time interval for the grafting success was probably long to maintain the flow of water and nutrients throughout the plant, causing the death of the vegetal part above the damage.

Despite the lower survival rate in plants with $80 \%$ of damaged stem under natural conditions, the damage caused by the stem borer gradually evolves, not being able to break the stem immediately, allowing after identification of the pest damage, the use of chemical control for conventional agriculture or use of natural insecticides in organic crops followed by restoration grafting, avoiding the increase in plant damage.

Productivity was affected by the damage caused to the passion fruit stem, with significant reduction in treatment with $80 \%$ damage caused by the reduction of the plant stand during production (Table 2), since there was no effect of the damage level on the average fruit mass and number of fruit per plant.

Even with mechanical injuries in up to $60 \%$ of the stem, the average productivity of the experiment was $7.8 \mathrm{t} \mathrm{ha}^{-1}$ in six months of evaluation, similar to the state average of $7.6 \mathrm{t} \mathrm{ha}^{-1}$ (IBGE, 2012), but higher than the productivity found by Araújo Neto et al. (2009) of 5.0 t ha $^{-1}$ in organic production system in the state of Acre, both considering a full harvest (10 months). Productivity data on this cropping system are scarce, and lower than average values obtained in Brazil (13.4 $\left.\mathrm{t} \mathrm{ha}^{-1}\right)$ and crop productive potential (50 $\left.\mathrm{t} \mathrm{ha}^{-1}\right)$, but similar to organic passion fruit production (ARAÚJO NETO Et al., 2014). The low productivity of the passion fruit crop is due to several factors, such as soil moisture, air temperature, photoperiod, genotype environment interaction, excess rainfall in pollination, low population of pollinators (COSTA et al., 2009; KRAUSE et al., 2012), and these factors may mask the effect of technologies tested in this culture.

The average fruit mass ranged from 117.7 to $126.5 \mathrm{~g}$, close to the Brazilian average of $120 \mathrm{~g}$ (AGRINUAL, 2012). This characteristic varies with production management system and passion fruit genetics, which ranges from 107.9 to $115.1 \mathrm{~g}$ fruit $^{-1}$ in dry or irrigated crop with different forms of fertilizer application (COSTA et al., 2009). Grafted plants may produce smaller fruits $\left(199 \mathrm{~g}^{\text {fruit }^{-1}}\right)$ compared to ungrafted plants (218 $\left.\mathrm{g} \mathrm{fruit}^{-1}\right)$ (CAVICHIOLI et al.,
2011). KRAUSE et al. (2012) evaluated commercial cultivars and harvested fruits with mass ranging from $132.5 \mathrm{~g}$ to $178.9 \mathrm{~g}$, only with natural pollination, and up to $274.3 \mathrm{~g}$ performing artificial pollination.

Larger fruits should be selected mainly for fresh consumption market (ASSUNÇÃO et al., 2015), because they present better commercial value, while smaller ones can be used in the fruit processing market, and the most important characteristics for this market segment are pulp percentage, total soluble solids and total acidity.

The variation coefficient (VC) ranged from 9.9 to $33.14 \%$ (Table 2). These estimates are in agreement with those obtained by Godoy et al. (2007) in experiments with evaluation of the yellow passion fruit agronomic performance, in which estimates from 2.0 to $29.0 \%$ were observed. However, Cavichioli et al. (2011), when studying passion fruit trees grafted on three passiflora species, observed VC above $100 \%$ for NFP and productivity.

Number of fruits per plant (NFP) between 20.8 and 37.7 is similar $(p<0.05)$ to 27 fruits per plant observed in studies with progenies of yellow passion fruit half-siblings (GONÇALVES et al., 2009). Total soluble solids, total titratable acidity and fruit ratio did not differ between plants with different damages (Table 3). Cavichioli et al. (2011) also did not find significant differences in soluble solids contents and total acidity of yellow passion fruits in different rootstocks.

Total soluble solids is a parameter used as reference for the quality of fruits aimed at pulp industrialization, which must have soluble solids content higher than $11^{\circ}$ Brix (BRASIL, 2000). The total soluble solids content ranged from 14.92 to 15.63 , higher than $(\mathrm{p}<0.05)$ that found by Janzantti et al. (2012) in organic farming (13.43) and conventional systems (14.71), and close to those found by Freitas et al. (2011), which ranged from 14.62 to 15.40 , in top accessions of passion fruit trees. In studies on intraspecific passion fruit grafting, these values ranged from 12.23 to 13.41 (CAVICHIOLI et al., 2011), being lower $(p<0.05)$ than those obtained in this study.

The total titratable acidity values ranged from 4.3 to $5.0 \%$, similar ( $>0.05$ ) to those found by Janzantti et al. (2012) of $4.3 \%$ in the organic system and higher $(\mathrm{p}<0.05)$ than in the conventional system (3.8\%). Comparing grafting types, Cavichioli et al. (2011), found total acidity of $3.9 \%$ in conventional grafting and $4.3 \%$ in hypocotylated grafting, which are values lower than $(p<0.05)$ and equal to $(p>0.05)$, respectively, those found in this study. These values exceeded the requirement of the Brazilian legislation, 
which establishes a minimum value of $2.5 \%$ for pulp (BRASIL, 2000) and $1.25 \%$ for non-sweetened juice (BRASIL, 2003).

Acidity in fruits for fresh consumption should be low, but related to soluble solids content, which should have a minimum ratio of 9: 1 , adequate to the consumer's taste (CHITARRA; CHITARRA, 2005). However, for high acidity as in passion fruit, it contributes to the reduction of the need for addition of acidifiers to the juice.
The ratio value expresses the sweet taste of fruits. Very high acidity helps reducing this ratio. The ratio found ranged from 3.0 to 3.6, being close ( $>0.05$ ) to those found by CAVICHIOLI et al. (2011), which ranged from 2.8 to 3.5 and Janzantti et al. (2012) for organic (3.19) and conventional cultivation (3.85).

The physicochemical characteristics analyzed (Table 3) are in accordance with Brazilian legislation for the industrialization and consumption of passion fruit pulp (BRASIL, 2000) and tropical juice (BRASIL, 2003), indicating that grafting did not impair these characteristics of fruits.

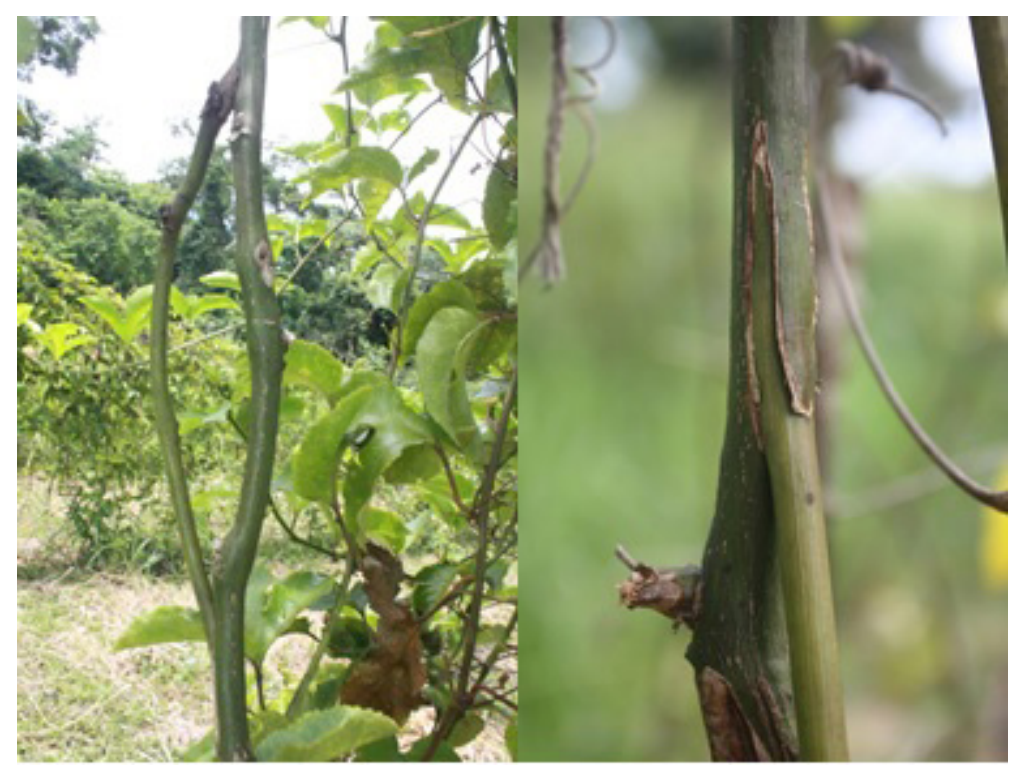

FIGURE 1 - Recovery grafting of the passion fruit stem. Photo: Maria Izabel (2013).

TABLE 1 - Grafting success percentage, plant survival rates on grafting and sub-grafting area of yellow passion fruit evaluated in August and September 2013, Rio Branco - AC.

\begin{tabular}{ccc}
\hline $\begin{array}{c}\text { Treatment } \\
(\% \text { damage })\end{array}$ & Grafting success percentage (\%) & Plant survival rates on grafting (\%) \\
\hline No damage & Not grafted & $100.0 \mathrm{a}$ \\
20 & $95.8 \mathrm{a}^{(1)}$ & $100.0 \mathrm{a}$ \\
40 & $81.3 \mathrm{a}$ & $87.5 \mathrm{~b}$ \\
60 & $93.8 \mathrm{a}$ & $100.0 \mathrm{a}$ \\
80 & $82.5 \mathrm{a}$ & $76.3 \mathrm{~b}$ \\
\hline
\end{tabular}

(1) Means followed by distinct letters in the column differ from each another by the Friedman test at $5 \%$ probability. 
TABLE 2 - Productivity (PROD), number of fruits per plant (NFP), average fruit mass (AFM) of grafted yellow passion fruit evaluated from September 13 to March 14, Rio Branco - AC.

\begin{tabular}{lccc}
\hline $\begin{array}{l}\text { Treatment } \\
(\% \text { damage })\end{array}$ & $\begin{array}{c}\text { PROD } \\
\left(\mathrm{kg} \mathrm{ha}^{-1}\right)\end{array}$ & NFP & $\begin{array}{c}\text { AFM } \\
(\mathrm{g})\end{array}$ \\
\hline No damage & $6,689.1 \mathrm{ab}$ & $27.1 \mathrm{a}$ & $117.7 \mathrm{a}$ \\
20 & $10,348.5 \mathrm{a}$ & $37.7 \mathrm{a}$ & $122.2 \mathrm{a}$ \\
40 & $6,777.0 \mathrm{ab}$ & $29.0 \mathrm{a}$ & $126.5 \mathrm{a}$ \\
60 & $7,559.75 \mathrm{ab}$ & $29.1 \mathrm{a}$ & $121.8 \mathrm{a}$ \\
80 & $3,802.8 \mathrm{~b}$ & $20.8 \mathrm{a}$ & $123.6 \mathrm{a}$ \\
\hline F test & $3.635^{*}$ & $1.6557 \mathrm{~ns}$ & $0.2813 \mathrm{~ns}$ \\
VC $(\%)$ & 33.14 & 32.7 & 9.9 \\
\hline
\end{tabular}

* Averages followed by the same letter in the column do not differ by the Tukey test at $5 \%$ of the error. ns - not significant at $5 \%$ level by the F test.

TABLE 3 - Total Soluble Solids (TSS), Total Titratable Acidity (TTA), TSS / TTA ratio of grafted yellow passion fruit evaluated from January to March 2014, Rio Branco-AC.

\begin{tabular}{cccc}
\hline $\begin{array}{c}\text { Treatment } \\
\text { (\%damage) }\end{array}$ & Total Soluble Solids (\%) & Total Titratable Acidity (\%) & TSS / TTA ratio \\
\hline No damage & 15.3 & 4.7 & 3.3 \\
20 & 15.3 & 4.3 & 3.6 \\
40 & 15.1 & 4.8 & 3.2 \\
60 & 15.6 & 4.6 & 3.4 \\
80 & 14.9 & 5.0 & 3.0 \\
\hline F test & $0.2579 \mathrm{~ns}$ & $0.7679 \mathrm{~ns}$ & $0.6428 \mathrm{~ns}$ \\
VC $(\%)$ & 6.8 & 12.8 & 17.9 \\
\hline
\end{tabular}

ns - not significant at $5 \%$ level by the $\mathrm{F}$ test.

\section{CONCLUSIONS}

Plants with $20 \%, 40 \%, 60 \%$ and $80 \%$ of damaged stem diameter when grafted with bridgetype graft, presented the same grafting success percentage and total soluble solids (TSS), total titratable acidity (TTA), TSS / TTA ratio, mean fruit mass and number of fruits per plant.

Bridge-type grafting recovers up to $76.3 \%$ of plants with up to $80 \%$ severe stem damage and up to $100 \%$ of plants with slight stem damage.

Stem restoration with bridge-type grafting allows passion fruit trees with up to $60 \%$ stem damage to maintain their productivity equal to that of healthy plants.

\section{ACKNOWLEDGMENTS}

To the Coordination for the Improvement of Higher Education Personnel and to the National Council of Scientific and Technological Development for granting scholarships to the authors.

\section{REFERENCES}

AGRIANUAL 2012: anuário da agricultura brasileira. São Paulo: FNP Consultoria \& comércio, 2012.

ANDRADE JUNIOR, V.C. de; ARAÚJO NETO, S.E. de; RAMOS, J.D.; RUFINI, J.C.; MENDONÇA, V. Produção de maracujazeiro-amarelo sob diferentes densidades de plantio. Pesquisa Agropecuária Brasileira, Brasília, DF, v.38, n.12, p.1381-1386, 2003. 
AOAC - Association of Official Analytical Chemists. Official methods of analysis. $19^{\text {th }}$ ed. Arlington: AOAC, 2012.

ARAÚJO NETO, S.E. de; CAMPOS, P.A.; TAVELLA, L.B.; SOLINO, A.J. da S.; SILVA, I.F. da. Organic polyculture of passion fruit, pineapple, corn and cassava: the influence of green manure and distance between espaliers. Ciência \& Agrotecnologia, Lavras, v.38, n.3, p.247-255, 2014.

ARAÚJO NETO, S.E.de; SOUZA, S.R.de; SALDANHA, C.S.; FONTINELE, Y.da R., NEGREIROS, J.R.da S.; MENDES, R.; AZEVEDO, J.M.A.de; OLIVEIRA, E.B. de L. Produtividade e vigor do maracujazeiro amarelo plantado em covas e plantio direto sob manejo orgânico. Ciência Rural, Santa Maria, v.39, n.3, p.678-683, 2009.

ASSUNÇÃO, M.P.; KRAUSE, W.; DALLACORT, R.; SANTOS, P.R.J dos; NEVES, L.G. Seleção individual de plantas de maracujazeiro azedo quanto à qualidade de frutos via REML/BLUP1. Revista Caatinga, Mossoró, v.28, n.2, p.57-63, 2015.

BRASIL. Ministério da Agricultura e do Abastecimento. Instrução normativa $\mathrm{n}^{\circ} 01$, de 7 de janeiro de 2000. Regulamento Técnico Geral para fixação dos Padrões de Identidade e Qualidade para polpa de fruta. Diário Oficial da República Federativa do Brasil, Brasília, DF, 10 jan. 2000. Disponível em: $<$ http://extranet.agricultura.gov.br/ sislegis-consulta/consultarLegislacao.do?operacao =visualizar\&id $=7777>$. Acesso em: 29 maio 2014.

BRASIL. Ministério da Agricultura, Pecuária e do Abastecimento. Instrução normativa $n^{\circ}$ 12, de 4 de setembro de 2003. Disponível em: $<$ http://extranet.agricultura.gov.br/sislegisconsulta/consultarLegislacao.do?operacao= visualizar\&id=2831>. Acesso em: 15 jun. 2014.

BRASIL. Ministério da Agricultura. Instrução Normativa $\mathrm{n}^{\circ} 46$ de 06 de outubro de 2011. Dispõe sobre as normas para produção orgânica de produtos vegetais e animais. Disponível em: $\leq$ www.agricultura. gov. br>. Acesso em: 17 set. 2014.
CAVICHIOLI, J.C.; CORREAA, L. de S.; BOLIANI, A.C.; SANTOS, P.C. dos. Características físicas e químicas de frutos de maracujazeiro amarelo enxertado em três porta-enxertos. Revista Brasileira de Fruticultura, Jaboticabal, v.33, n.3, p.905-914, 2011.

CÉSAR, H. P. Manual prático do enxertador: e criador de mudas de árvores frutíferas e dos arbustos ornamentais. 14.ed. São Paulo: Nobel, 1986.

Chitarra, M. I. F.; Chitarra, A. B. Póscolheita de frutas e hortaliças: fisiologia e manuseio. 2 ed. rev.e ampl. Lavras: UFV, 2005. 785p.

COSTA, M.M.; BONOMO, R.; SENA JÚNIOR, D.G.de; GOMES FILHO, R.R.; RAGAGNIN, V.A. Produção do maracujazeiro amarelo em condições de sequeiro e irrigado em Jataí - GO. Revista Brasileira de Agricultura Irrigada, Fortaleza, v.3, n.1, p.13-21, 2009.

CRASWELLER, R. M. Grafting and Propagating Fruit Trees. Pennsylvania: Penn State's College of Agricultural Sciences, Pennsylvania State University, University Park, 2005.

FACHINELLO, J.C.; HOFFMANN, A.; NACHTIGAL, J.C. Propagação de plantas frutíferas. Brasília, DF: Embrapa Informação Tecnológica, 2005. 221p.

FADINI, M.A.M.; SANTA-CECÍLIA, L.V.C. Manejo integrado de pragas do maracujazeiro. In: EPAMIG. A cultura do maracujazeiro. Informe Agropecuário, Belo Horizonte, v.21, n.206, p.2933, 2000.

FANCELLI, M.; LIMA, A. de A. Insetos - praga do maracujazeiro. In: LIMA, A. de A.; CUNHA, M. A. P. da. Maracujá: produção e qualidade na passicultura. Cruz das Almas: Embrapa Mandioca e Fruticultura, 2004. p.179-209.

FREITAS, J.P.X.; OLIVEIRA, E.J.; CRUZ NETO, A.J.; SANTOS, L.R. Avaliação dos recursos genéticos de maracujazeiro amarelo. Pesquisa Agropecuária Brasileira, Brasílai, DF, v.46, p.10131020, 2011. 
GODOY, R. C. B. de; LEDO, C. A. da S.; SANTOS, A. P. dos; MATOS, E. L. S.; LIMA, A. de A.; WASZCZYNSKYJ, N. Diversidade genética entre acessos de maracujazeiro amarelo avaliada pelas características físico-químicas dos frutos. Ceres, Viçosa, MG, v.54, n.316, p:541-547, 2007.

GONÇALVES, G.M.; VIANA, A.P.; PEREIRA, M.G.; BEZERRA NETO, V.; AMARAL JÚNIOR, A.T. do; PEREIRA, T.N.S.; GONÇALVES, T.J.M. Genetic parameter estimates in yellow passion fruit based on design I. Brazilian Archives of Biology and Technology, Curitiba, v.52, n.3, p.523-530, 2009.

IBGE - Sistema IBGE de recuperação automática. Produção agrícola municipal 2012. Rio de Janeiro: IBGE, 2013. Disponível em: <http:// www.sidra.ibge.gov.br/bda/tabela/protabl. asp?c $=1613 \& \mathrm{z}=\mathrm{t} \& \mathrm{o}=11 \& \mathrm{i}=\mathrm{P}>$. Acesso em: $14 \mathrm{jun}$. 2014.

JANZANTTI, N.S.; MACORIS, M.S.; DEBORAH, S.; GARRUTI, D.S.; MONTEIRO, M. Influence of the cultivation system in the aroma of the volatile compounds and total antioxidant activity of passion fruit. LWT - Food Science and Technology, Amsterdam, v.46, p.511-518, 2012.

KRAUSE, W.; NEVES, L.G.; VIANA, A.P.; ARAÚJO, C.A.T.; FALEIRO, F.G. Produtividade e qualidade de frutos de cultivares de maracujazeiro amarelo com ou sem polinização artificial. Pesquisa Agropecuária Brasileira, Brasília, DF, v.47, n.12, p.1737-1742, dez. 2012
LIMA, B.M.F.V.; MOREIRA, J.O.T.; ARAGÃO, C.A. Avaliação de extratos vegetais no controle de mosca-branca, Bemisia tabaci biótipo B em abóbora. Revista Ciência Agronômica, Fortaleza, v. 44, n. 3 , p. $622-627,2013$.

MAPA. AGROFIT 2011 - Desenvolvido pelo Ministério da Agricultura, Pecuária e Abastecimento. 2011. Apresenta informações sobre produtos fitossanitários. Disponível em: <http://www. agricultura.gov.br/agrofit $>$. Acesso em: 10 jun. 2014

RONCATTO, G.; ASSIS, G.M.L. de; OLIVEIRA, T.K. de; LESSA, L.S. Aspectos vegetativos de combinações copa/ porta-enxerto em maracujazeiro.

Revista Brasileira de Fruticultura, Jaboticabal, v.33, n.3, p.791-797, 2011 b.

RONCATTO, G.; LENZA, J.B.; VALENTE, J.P. Modalidades de enxertia para maracujazeiro: avaliação preliminar nas condições da depressão cuiabana. Comunicação Cientifica. Revista Brasileira de Fruticultura, Jaboticabal, v.33, n.1, p.316-320, 2011a.

SILVA, R.M. das; AGUIAR, A.V.M. de; CARDOSO, E. de A.; SOUZA, J. de O.; OLIVEIRA, L.A. de A. Enxertia interespecífica do maracujazeiro amarelo sobre quatro porta-enxertos. Revista Verde, Mossoró, v.6, n. 2, 2011. 